\title{
Drought tolerance of local dryland rice varieties from the far western Santa Catarina,
}

\section{Brazil}

Tolerância à seca de variedades locais de arroz de sequeiro do extremo oeste de Santa Catarina, Brasil

Tolerancia a la sequía de variedades locales de arroz de secano del extremo occidental de Santa Catarina, Brasil

Otavio Rechsteiner Maghelly ORCID: https://orcid.org/0000-0001-9918-4177 Federal University of Santa Catarina, Brazil E-mail: otavio.maghelly@ufsc.br

Juliana Bernardi Ogliari ORCID: https://orcid.org/0000-0003-2644-3179 Federal University of Santa Catarina, Brazil E-mail: juliana.bernardi@ufsc.br

Francisco Wilson Reichert Júnior ORCID: https://orcid.org/0001-0002-4501-898X Federal University of Santa Catarina, Brazil E-mail: chicowrj@gmail.com Nuno de Campos Filho ORCID: https://orcid.org/0000-0003-1689-4531 Federal University of Santa Catarina, Brazil E-mail: nuno.campos@ufsc.br

Rosenilda de Souza

ORCID: https://orcid.org/0000-0001-7820-2516 Federal University of Santa Catarina, Brazil E-mail: rosenilda.agro@hotmail.com

Tassiane Terezinha Pinto

ORCID: https://orcid.org/0000-0001-6575-7635 Federal University of Santa Catarina, Brazil E-mail: tassi.tp@gmail.com

\begin{abstract}
Drought is the main factor of abiotic stress in dryland rice cultivation, responsible for considerable productivity losses and grain quality damages, as well as genetic erosion of local varieties of this crop. The use of indices in the drought tolerance estimation in grains of this crop is acquiring importance for its advantages in the operationalization of tests of comparison between genotypes and their effectiveness in the differentiation of responses to drought stress. Among local dryland varieties of rice preserved by small-scale farmers in far western Santa Catarina, different responses to drought tolerance are expected. The identification of these differential responses is important in the context of agrobiodiversity conservation, genetic improvement, and as an alternative to the effects of climate changes. The objective of the present study was to evaluate thirty-four local varieties of dryland rice from far western Santa Catarina regarding drought tolerance. For this aim, this work used the DTD (Drought Tolerance Degree) methodology. Fifteen varieties showed greater resistance when submitted to a water restriction level of $10 \%$ in water moisture. On the other hand, six varieties were more resistant to moderate stress $(20 \%)$. Finally, three varieties were among the most resistant in the two applied stress levels.
\end{abstract}

Keywords: Dryland rice; Drought tolerance; Climate changes.

\section{Resumo}

A seca é o principal fator de estresse abiótico em cultivos de arroz de sequeiro, sendo a responsável por consideráveis perdas de produtividade e danos à qualidade dos grãos, bem como à erosão genética de variedades locais deste cultivo. $\mathrm{O}$ uso de índices na estimativa da tolerância à seca nos grãos da cultura está ganhando importância por suas vantagens na operacionalização dos testes de comparação entre genótipos e sua eficácia na diferenciação das respostas ao estresse hídrico. Entre as variedades locais de arroz conservadas por pequenos agricultores, no extremo oeste de Santa Catarina, esperam-se diferentes respostas à tolerância à seca. A identificação dessas respostas diferenciais é importante no contexto da conservação da agrobiodiversidade, do melhoramento genético e como uma alternativa aos efeitos das 
mudanças climáticas. O objetivo do presente estudo foi avaliar trinta e quatro variedades locais de arroz de arroz de sequeiro do extremo oeste de Santa Catarina para a tolerância à seca. Para este fim, este trabalho utilizou a metodologia DTD (Drought Tolerance Degree). Quinze variedades mostraram maior resistência quando sujeitas a um nível de restrição de água de $10 \%$ na solução do solo. Por outro lado, seis variedades foram mais tolerantes ao estresse moderado (20\%). Finalmente, três variedades estavam entre as mais resistentes em ambos os níveis de estresse.

Palavras-chave: Arroz de sequeiro; Tolerância à seca; Mudanças climáticas.

\section{Resumen}

La sequía es el principal factor de estrés abiótico en los cultivos del arroz de secano, responsable de considerables pérdidas de productividad y daños en la calidad del grano, así como de la erosión genética con pérdidas de variedades locales en casos extremos. El uso de índices en la estimación de la tolerancia a la sequía en los granos del cultivo está adquiriendo importancia por sus ventajas en la operacionalización de pruebas de comparación entre genotipos y su efectividad en la diferenciación de respuestas al estrés por sequía. Entre las variedades locales de arroz de secano conservadas por los pequeños agricultores del extremo occidental de Santa Catarina, se esperan diferentes respuestas a la tolerancia a la sequía. La identificación de estas respuestas diferenciales es importante en el contexto de la conservación de la agrobiodiversidad, la mejora genética y como alternativa a los efectos de los cambios climáticos. El objetivo del presente estudio fue evaluar treinta y cuatro variedades locales de arroz de secano del extremo occidental de Santa Catarina en cuanto a la tolerancia a la sequía. Para ello, este trabajo utilizó la metodología DTD (Drought Tolerance Degree). Quince variedades mostraron mayor resistencia cuando fueron sometidas a un nivel de restricción hídrica del 10\% en la solución del suelo. Por otro lado, seis variedades fueron más resistentes al estrés moderado (20\%). Finalmente, tres variedades estuvieron entre las más resistentes en los dos niveles de estrés aplicados.

Palabras clave: Arroz de secano; Tolerancia a la sequía; Cambios climáticos.

\section{Introduction}

The plant development, productivity and industrial quality of dryland rice are strongly affected by biotic and abiotic stresses (Zu et al., 2017). Rice is one of the most susceptible agricultural crops to water stress because of its small root system, its little circular wax during mild water stress and rapid stomach closure (Ji, Wang \& Sun, 2012). The critical periods of sensitivity are the initial periods of emergence and establishment of seedlings and the pre-flowering and grain-filling phases (Adhikari, Adhikari, Sharma, Gairhe, Bhandari \& Paudel, 2019). Water stress is the most harmful and widespread of all environmental stresses, occurring on different continents and affecting more than 23 million hectares just in Asia, with productivity losses exceeding 40\% (Adhikari et al., 2019; IRRI, 2019). Stone, Libardi \& Reichardt (1986) reported productivity losses up to $87 \%$ with eight days of induced hydric stress in a variety of dryland rice, at the beginning of panicle emissions.

In far western Santa Catarina, small-scale farmers have been conserving local varieties of dryland rice for several decades, mainly for family self-consumption (Pinto, 2017). The on-farm conservation of these local varieties plays an important role in families' food security and in maintaining the culinary traditions of the communities, in addition to promoting the conservation of the genetic diversity of the species and future possible use as a source of genes and characteristics for breeding programs. The first study on the diversity of dryland rice in this region from 112 local populations identified different morphological groups in terms of grain shape and color, within the japonica and indica subgroups, and a new subgroup mixing the characteristics of the first two (Pinto, Ogliari \& Maghelly, 2019).

Drought is the main abiotic factor that affects the production and conservation of local varieties of dryland rice. Drought is the main reason associated with the loss of dryland rice seeds in the region, being an important factor in the process of genetic erosion of this genetic resource (Pinto et al., 2019). In a period of 34 years, from 1979 to 2013, some municipalities in the region have already decreed fifteen times "emergency situations" due to droughts (Marchesan \& Comassetto, 2019). According to Freitas and Oliveira (2018), there has been a greater concentration and recurrence of long droughts in the first months of the year, which coincides with the critical periods of sensitivity of rice plants to hydric stress (pre-flowering and grain-filling phases).

Among the predicted impacts of global climate changes for the next decades is the change in water cycle regimes, resulting in alterations in local rainfall rates and more frequent droughts or flood events (Shanker et al., 2014). Other effects 
noted in climate change scenarios are increases in seasonal temperature associated with reduced precipitation and increased frequency, intensity, and duration of heat waves (Lana, Eulestein \& Schlindwein, 2017). In Brazil, the temperature is expected to increase in all biomes and rainfall is expected to decrease, except for the Pampas and the Atlantic Forest (Gondim, Figueiredo, Maia, Bezerra \& Carvalho, 2017). According to the report of the Intergovernmental Panel on Climate Center (2013), the increase in average temperature by $1{ }^{\circ} \mathrm{C}$ can already have a negative impact on rice cultivation in tropical areas. In this sense, it is imperative to evaluate the differential response of dryland rice populations and varieties to water stress situations, as alternatives for crop recommendations to small-scale farmers, strategies for agrobiodiversity conservation, and genetic improvement.

The mechanism of tolerance to water stress is complex, influenced by variations in plant phenology and controlled by various quantitative loci (Sahebi et al., 2018). Several methods have been used to evaluate the drought tolerance of agricultural crops, mainly related to seed germination, productivity, and survival rate. However, these characters are of complex formation and influenced by many variables (Xiao, Chen, Xiang, Tang, Zhang \& Xiong, 2009). Physiological methods, based on the accumulation of abscisic acid, evaluation of water potential, proline, malonaldehyde and chlorophyll contents estimate the damage caused to leaves under water stress and constitute an indirect method of estimation (Dingkuhn, Dorffling, Javellana \& Datta, 1989; Blum, 2016).

For $\mathrm{Zu}$ et al. (2017), the development of improved varieties of dryland rice for hydric stress tolerance depends on the identification of highly tolerant accesses to this stress, by means of a fast, efficient, and capable method of rapidly differentiating the result of the crossings, until the selection process of superior materials is concluded. Jaldhani, Sengutuvel, Srikanth, Rao, Subrahmanyam \& Rao (2021) report the narrow genetic base of cultivars with drought tolerance and the limitations of conventional breeding programs, related to the difficulty to identify drought tolerant variants in field conditions.

Ouk et al. (2006) recognized that the difficulty in identifying drought tolerant materials is one of the main challenges in rice genetic improvement and adapted an index based on comparative loss of productivity in drought condition, the DRI- Drought Response Index. However, despite the high correlations obtained, the method developed by these authors are specific to a variety or group of related varieties and would still have the disadvantage for experimentation, due to the need to lead many populations to the end of the crop cycle.

The use of drought tolerance indices in the grain genetic improvement, replacing the differential analysis of yield components and physiological response parameters, has gained importance in recent years by the possibility of testing many genotypes in shorter periods of time and with lower requirements for complex equipment and protocols (Eyd \& Sabry, 2019; Sabagh et al., 2018). Different authors working with the evaluation of stress and hydric stress tolerance indices in rice genotypes have concluded that the indices are effective and useful in the identification of superior genotypes regarding drought tolerance (Kumar et al., 2014; Adhikari et al., 2019; Garg \& Bhattacharya, 2017; Zu et al., 2017). Zu et al. (2017), working with thirty varieties of rice, submitted to different levels of water stress, proposed the use of the Drought Tolerance Degree (DTD), based on the dry and severely damaged leaf lengths of the three upper leaves of the rice plant at the beginning of the crop cycle. This method proved to be easy and fast to measure, besides being strong and significantly correlated with physiological characters related to hydric stress responses, in advanced phases of the rice cycle, such as the water potential in the leaves, the proline content (an important substance in the osmotic balance of plant cells), chlorophyll and malonaldehyde (it acts as an indicator of oxidation and occurrence of damage in lipidic membranes). In the work of Zu et al. (2017), the DTD also presented high Pearson correlation coefficients with the end-of-cycle yield components, such as survival rate ( $\mathrm{r}=0.9848)$, number of panicles per plant $(\mathrm{r}=0.8953)$, number of fertile spikelets per panicle $(\mathrm{r}=0.9714)$ and productivity per plant $(\mathrm{r}=0.9487)$. Based on this methodology, the objective of the present work was to evaluate the degree of drought tolerance of dryland rice varieties conserved in the far western Santa Catarina, in order to establish a ranking of varieties drought tolerance. 


\section{Methodology}

The experiment was conducted in a plastic greenhouse of Federal University of Santa Catarina - UFSC experimental farm, in October and November 2019.

The experimental farm is located in Florianópolis, at the geographical coordinates $27^{\circ} 41^{\prime} 06.28^{\prime \prime}$ S; 48 32' $38.81^{\prime \prime}$ O. According to the Köeppen climatic classification, the farm is in a subtropical sub-region of constantly humid climate, without dry season, with hot summer. The average annual relative humidity varies around $82 \%$, with total annual sunlight from 2021 to 2166 hours and average temperature of $20.1^{\circ} \mathrm{C}$.

The local varieties of dryland rice were collected between 2012 and 2014 by the researcher's team of the UFSC (Study Nucleus in Agrobiodiversity - NEABio), at small-scale farmers from the municipalities of Anchieta and Guaraciaba, in the far western Santa Catarina.

The selection of the thirty-four local varieties for the experiment was based on the morphological and phenological dissimilarity of the populations evaluated in the study by Pinto et al. (2019). These varieties represent the genetic diversity of local rice populations of Anchieta and Guaraciaba for number of tillers, thatch thickness and panicle length, with more than $95 \%$ precision. The statistical control variety used was the IPR117, developed by Agronomic Institute of Paraná (IAPAR/PR), which is the only dryland variety with commercial seed production and cultivation recommendation for southern Brazil.

For the evaluation of drought tolerance, two levels of water stress were used: $10 \%$ (severe stress) and 20\% (moderate stress) of water in the soil solution. The control treatment was $50 \%$ of water in the soil solution, considered a normal saturation (no stress). The experiment was conducted in an experimental design of complete randomized blocks, in the scheme of split plot design, with three replications, having as splits the stress levels and as plots the varieties of dryland rice. The design and statistical methodological procedures were based on Sokal and Rohlf (2012).

Each experimental unit was composed of a tray of 30 cells, with 0.126 liters volume each one and the substrate used was composed of $80 \%$ of quartz neosoil and $20 \%$ of poultry manure.

After sowing, the varieties were held for 30 days in a floating system, with water saturation in the soil solution close to $50 \%$. During this period, the plants developed to the average vegetative stage between V6 and V7, according to stages described by Counce, Keisling and Mitchell (2000).

On the 31 st day after sowing, the water stress treatments started with $10 \%, 20 \%$ and $50 \%$ of water in the soil solution. The floating system was drained and all the water entering the system was done through controlled irrigation.

Water volumetry readings in the soil solution were performed three times a day ( $8 \mathrm{~h}, 12 \mathrm{~h}$ and $16 \mathrm{~h}$ ); with an Icel brand instantaneous soil hygrometer and replacement of the necessary volume of water to maintain the water percentages of the treatments. At the same times, data on temperature $\left({ }^{\circ} \mathrm{C}\right)$, relative humidity $(\%)$ and solar radiation (LUX) were collected inside the greenhouse, using an electronic meter, brand Hikari model Htm-401. The stress was applied from the 31st to the 42nd day after sowing, totaling 12 days. On the 43rd day, the floating system was supplied again, and all the experimental units were left for three days with soil water saturation close to $50 \%$, in order to differentiate temporary wilting from permanent damage. Data collection took place on the 46th and 47 th day, after sowing.

The length of the green and total leaf was measured, of the three upper leaves, totally differentiated, of each plant (Figure 1). 
Figure 1: Schematic drawing of the leaf length measurements collected after induced stress period.

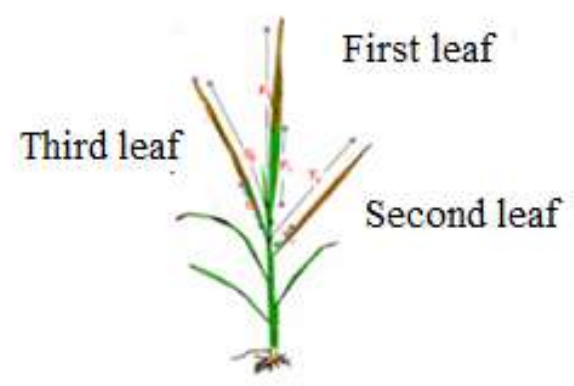

Source: Adapted from Zu et al. (2017)

The Drought Tolerance Degree (DTD) index proposed by Zu et al. (2017) was used to differentiate drought tolerance of local varieties. For the DTD calculation, a data of this proportion per plant was generated, through the following formula: $\mathrm{X}_{\mathrm{j}}=$ $1 / \mathrm{n}_{i=1}^{n} \sum\left(\left(\mathrm{F}_{1} / \mathrm{F}_{2}+\mathrm{S}_{1} / \mathrm{S}_{2}+\mathrm{T}_{1} / \mathrm{T}_{2}\right) / 3\right)$, where: $\mathrm{F}_{1}=$ first leaf green length in $\mathrm{cm} ; \mathrm{F}_{2}=$ total leaf in $\mathrm{cm} ; \mathrm{S}_{1}=$ second leaf green length in $\mathrm{cm} ; \mathrm{S}_{2}=$ total leaf in $\mathrm{cm} ; \mathrm{T}_{1}=$ third leaf green length in $\mathrm{cm} ; \mathrm{T}_{2}=$ total leaf in $\mathrm{cm}$, of each plant.

After calculating the individual $\mathrm{X}_{\mathrm{j}}$ per plant, the average of each experimental unit (30 plants) was calculated and the DTD index was obtained from the following formula: DTD $=\left(X_{I}+X_{I I}+X_{I I I}\right)$, where $X_{I}, X_{I I}, X_{I I I}$ refer to the repetitions $(Z u$ et al. 2017).

Previous analyses of homoscedasticity were done and after the assumptions were verified, the analysis of variance for the DTD variable was carried out. Significant differences between varieties, stress levels and for variety x stress level interaction by the F test $(\mathrm{p} \leq 0.05)$ were followed by the Scott-Knot test at the same level of significance.

All statistical analyses were done with the SISVAR computer application (Ferreira, 2019).

\section{Results and Discussion}

During the period of induced hydric stress, the temperature inside the greenhouse varied from 24.8 to $44.2^{\circ} \mathrm{C}$, with an average of $33{ }^{\circ} \mathrm{C}$. The relative humidity was between 39.8 and $77.2 \%$, with an average of 52\%, and the solar radiation between 7200 and 21000 LUX, with an average of 13832 LUX (Table 1). 
Table 1: Climatological data obtained during the period of induced hydric stress, from instantaneous reading electronic equipment.

\begin{tabular}{|c|c|c|c|c|c|c|c|c|c|}
\hline \multirow[t]{2}{*}{ DAS $^{1}$} & \multicolumn{3}{|c|}{ Temperature $\left({ }^{\circ} \mathrm{C}\right)$} & \multicolumn{3}{|c|}{ Relative humidity (\%) } & \multicolumn{3}{|c|}{ Solar radiation (LUX) } \\
\hline & 08:00 & 12:00 & 16:00 & 08:00 & 12:00 & 16:00 & 08:00 & 12:00 & 16:00 \\
\hline 31 & 26.9 & 33.1 & 28.9 & 64.0 & 65.0 & 60.1 & 7200 & 12300 & 9800 \\
\hline 32 & 31.0 & 41.0 & 34.9 & 50.0 & 61.2 & 57.4 & 11000 & 13000 & 10100 \\
\hline 33 & 30.0 & 39.7 & 35.4 & 49.6 & 47.0 & 45.0 & 10500 & 14700 & 11200 \\
\hline 34 & 28.2 & 36.6 & 33.1 & 48.3 & 46.5 & 42.0 & 9800 & 16000 & 13000 \\
\hline 35 & 32.0 & 33.9 & 37.4 & 49.1 & 62.0 & 55.4 & 15470 & 18490 & 16385 \\
\hline 36 & 25.3 & 27.8 & 25.4 & 65.1 & 77.2 & 68.7 & 6980 & 12000 & 15400 \\
\hline 37 & 24.8 & 27.5 & 26.0 & 62.8 & 72.5 & 66.0 & 7830 & 13400 & 14720 \\
\hline 38 & 27.2 & 34.0 & 33.3 & 54.0 & 37.3 & 39.6 & 14400 & 21000 & 17660 \\
\hline 39 & 31.4 & 42.5 & 34.8 & 49.3 & 36.5 & 40.2 & 13200 & 20600 & 16200 \\
\hline 40 & 30.8 & 44.2 & 36.1 & 48.5 & 37.8 & 42.8 & 14000 & 20100 & 15700 \\
\hline 41 & 26.5 & 31.0 & 29.3 & 49.0 & 48.3 & 46.0 & 11600 & 13000 & 14200 \\
\hline 42 & 32.1 & 38.5 & 36.2 & 48.6 & 39.8 & 48.9 & 12700 & 17800 & 16500 \\
\hline
\end{tabular}

1 - DAS: Days after sowing. Source: Authors.

The occurrence of high temperatures with the consequent reduction of the air relative humidity inside the greenhouse may have anticipated and potentialized the physiological effects and the expression of the drought responses. After 12 days of water restriction, all the experimental units of the 10 and $20 \%$ treatments showed evident signs of drought stress and plants with parts or all the dry leaves and with severe damage.

The DTD index values calculated for the varieties, in the different stress levels, varied from 0.4000 to 0.9972 . On average, the varieties submitted to 10 and $20 \%$ stress showed significant differences for DTD, in relation to the control treatment (Table 2). 
Research, Society and Development, v. 10, n. 8, e55310817705, 2021

(CC BY 4.0) | ISSN 2525-3409 | DOI: http://dx.doi.org/10.33448/rsd-v10i8.17705

Table 2: DTD of local dryland rice varieties after a period of induced hydric stress.

\begin{tabular}{|c|c|c|c|c|}
\hline \multirow[b]{2}{*}{ Varieties } & \multicolumn{3}{|c|}{ Soil water levels } & \multirow[b]{2}{*}{ Mean } \\
\hline & $10 \%$ & $20 \%$ & $50 \%$ & \\
\hline 7 & $0.6525 \mathrm{aB}$ & $0.6690 \mathrm{bB}$ & $0.9736 \mathrm{aA}$ & $0.7660 \mathrm{a}$ \\
\hline 10 & $0.4691 \mathrm{bC}$ & $0.6931 \mathrm{bB}$ & $0.9681 \mathrm{aA}$ & $0.6912 \mathrm{~b}$ \\
\hline 12 & $0.6661 \mathrm{aB}$ & $0.6711 \mathrm{bB}$ & $0.9641 \mathrm{aA}$ & $0.8038 \mathrm{a}$ \\
\hline 13 & $0.5312 \mathrm{bB}$ & $0.7034 \mathrm{bB}$ & $0.9712 \mathrm{aA}$ & $0.7353 \mathrm{a}$ \\
\hline 14 & $0.6114 \mathrm{aB}$ & $0.6682 \mathrm{bB}$ & $0.9575 \mathrm{aA}$ & $0.7235 \mathrm{a}$ \\
\hline 17 & $0.5928 \mathrm{bB}$ & $0.6502 \mathrm{bB}$ & $0.9736 \mathrm{aA}$ & $0.7388 \mathrm{a}$ \\
\hline 19 & $0.7379 \mathrm{aB}$ & $0.7280 \mathrm{bB}$ & $0.9695 \mathrm{aA}$ & $0.8118 \mathrm{a}$ \\
\hline 20 & $0.5428 \mathrm{bB}$ & $0.6128 \mathrm{bB}$ & $0.9575 \mathrm{aA}$ & $0.6821 \mathrm{~b}$ \\
\hline 22 & $0.4680 \mathrm{bC}$ & $0.6365 \mathrm{bB}$ & $0.9667 \mathrm{aA}$ & $0.6216 \mathrm{~b}$ \\
\hline 24 & $0.5277 \mathrm{bB}$ & $0.6840 \mathrm{bB}$ & $0.9703 \mathrm{aA}$ & $0.7113 \mathrm{~b}$ \\
\hline 29 & $0.7136 \mathrm{aB}$ & $0.6988 \mathrm{bB}$ & $0.9781 \mathrm{aA}$ & $0.7565 \mathrm{a}$ \\
\hline 31 & $0.6246 \mathrm{aB}$ & $0.6748 \mathrm{bB}$ & $0.9636 \mathrm{aA}$ & $0.7468 \mathrm{a}$ \\
\hline 32 & $0.7112 \mathrm{aB}$ & $0.6217 \mathrm{bB}$ & $0.9693 \mathrm{aA}$ & $0.7789 \mathrm{a}$ \\
\hline 34 & $0.6840 \mathrm{aB}$ & $0.7368 \mathrm{bB}$ & $0.9570 \mathrm{aA}$ & $0.8112 \mathrm{a}$ \\
\hline 35 & $0.6683 \mathrm{aB}$ & $0.6103 \mathrm{bB}$ & $0.9804 \mathrm{aA}$ & $0.7653 \mathrm{a}$ \\
\hline 41 & $0.4000 \mathrm{bC}$ & $0.6794 \mathrm{bB}$ & $0.9620 \mathrm{aA}$ & $0.6454 \mathrm{~b}$ \\
\hline 42 & $0.5708 \mathrm{bB}$ & $0.6900 \mathrm{bB}$ & $0.9794 \mathrm{aA}$ & $0.6899 \mathrm{~b}$ \\
\hline 43 & $0.6333 \mathrm{aB}$ & $0.7044 \mathrm{bB}$ & $0.9612 \mathrm{aA}$ & $0.7603 \mathrm{a}$ \\
\hline 50 & $0.6505 \mathrm{aB}$ & $0.6912 \mathrm{bB}$ & $0.9791 \mathrm{aA}$ & $0.8123 \mathrm{a}$ \\
\hline 54 & $0.4448 \mathrm{bB}$ & $0.5891 \mathrm{bB}$ & $0.9760 \mathrm{aA}$ & $0.6828 \mathrm{~b}$ \\
\hline 59 & $0.5505 \mathrm{bB}$ & $0.5354 \mathrm{bB}$ & $0.9854 \mathrm{aA}$ & $0.7451 \mathrm{a}$ \\
\hline 60 & $0.6115 \mathrm{bB}$ & $0.6496 \mathrm{bB}$ & $0.9509 \mathrm{aA}$ & $0.6319 \mathrm{~b}$ \\
\hline 61 & $0.6449 \mathrm{aB}$ & $0.8268 \mathrm{aA}$ & $0.9656 \mathrm{aA}$ & $0.7743 \mathrm{a}$ \\
\hline 67 & $0.6222 \mathrm{aB}$ & $0.6809 \mathrm{bB}$ & $0.9605 \mathrm{aA}$ & $0.8527 \mathrm{a}$ \\
\hline 68 & $0.5358 \mathrm{bB}$ & $0.6935 \mathrm{bB}$ & $0.9677 \mathrm{aA}$ & $0.6541 \mathrm{~b}$ \\
\hline 71 & $0.7283 \mathrm{aB}$ & $0.7326 \mathrm{aB}$ & $0.9713 \mathrm{aA}$ & $0.8285 \mathrm{a}$ \\
\hline 72 & $0.5034 \mathrm{bB}$ & $0.6882 \mathrm{bB}$ & $0.9555 \mathrm{aA}$ & $0.7587 \mathrm{a}$ \\
\hline 82 & $0.6825 \mathrm{aB}$ & $0.7357 \mathrm{aB}$ & $0.9855 \mathrm{aA}$ & $0.7531 \mathrm{a}$ \\
\hline 83 & $0.5194 \mathrm{bB}$ & $0.7156 \mathrm{bB}$ & $0.9424 \mathrm{aA}$ & $0.7193 \mathrm{~b}$ \\
\hline 84 & $0.5316 \mathrm{bB}$ & $0.7584 \mathrm{aB}$ & $0.9437 \mathrm{aA}$ & $0.7711 \mathrm{a}$ \\
\hline 90 & $0.5133 \mathrm{bC}$ & $0.7559 \mathrm{aB}$ & $0.9679 \mathrm{aA}$ & $0.6752 \mathrm{~b}$ \\
\hline 98 & $0.4555 \mathrm{bC}$ & $0.5004 \mathrm{bB}$ & $0.9494 \mathrm{aA}$ & $0.6315 \mathrm{~b}$ \\
\hline 103 & $0.5619 \mathrm{bB}$ & $0.7412 \mathrm{aB}$ & $0.9750 \mathrm{aA}$ & $0.7705 \mathrm{a}$ \\
\hline 104 & $0.6048 \mathrm{bB}$ & $0.6620 \mathrm{bB}$ & $0.9508 \mathrm{aA}$ & $0.7391 \mathrm{a}$ \\
\hline IPR117 & $0.4320 \mathrm{bC}$ & $0.5997 \mathrm{bB}$ & $0.9972 \mathrm{aA}$ & $0.6762 \mathrm{~b}$ \\
\hline Mean & $0.5660 \mathrm{~b}$ & $0.6712 \mathrm{~b}$ & $0.9671 \mathrm{a}$ & 0.7347 \\
\hline $\mathrm{CV}(\%)^{1}$ (residuo a) & & 13.36 & & \\
\hline
\end{tabular}


Research, Society and Development, v. 10, n. 8, e55310817705, 2021

(CC BY 4.0) | ISSN 2525-3409 | DOI: http://dx.doi.org/10.33448/rsd-v10i8.17705

\begin{tabular}{lc}
\hline \multicolumn{1}{c}{$\mathrm{CV}(\%)^{2}($ residuo $\mathrm{b})$} & 16.19 \\
\hline \multicolumn{1}{c}{ Prob test F stress } & $0.0129 * *$ \\
\hline Prob test F Varieties & $0.0002 * *$ \\
\hline Prob test F Interaction & $0.3139 * *$
\end{tabular}

Variety averages and stress level averages followed by the same letter do not differ by the Scott-Knot test at the 0.05 significance level. Values followed by the same lowercase letter in the rows and the same uppercase letter in the columns do not differ by the Scott-Knot test at the 0.05 significance level.

1- $\quad \mathrm{CV}$ a (from the splits) $=\frac{\sqrt{Q M a}}{\frac{m}{6 M b}} \cdot 100$
2- $\quad \mathrm{CV} \mathrm{b}$ (from the plots) $=\frac{\sqrt{Q M b}}{m} .100$
$* *$ - significant $\mathrm{F}$ test at $\mathrm{p}<0.01$. Source: Authors

As for the response of the varieties to the most severe stress (10\%), fifteen varieties showed greater resistance when submitted to this level of water restriction $(7,12,14,19,29,31,32,34,35,43,50,61,67,71$ and 82$)$. Six varieties $(61.71,82,84,90$ and 103) were more resistant to moderate stress. It should be noted that varieties 61,71 and 82 were among the most resistant in both levels of stress applied.

According to $\mathrm{Zu}$ et al. (2017), DTD values closer to 1.0, the smaller the parts of the leaves that are dry and severely damaged and the greater the tolerance of the plant to hydric stress. In their work, varieties with DTD between 0.65 and 0.78 presented a reduction of about $57 \%$ in productivity per plant, while varieties with DTD close to 0.40 presented a $68 \%$ reduction in productivity per plant.

Comparing the DTD relation with the productivity reduction data obtained by Zu et al. (2017), the local varieties positioned in the upper groups of means in the present work, for treatments 10 and 20\%, would present theoretical potential to maintain a little less than half of their productive capacity even after being submitted to stress conditions similar to those applied in the experiment.

Information provided by farmers, in the municipalities where the seeds were collected, classified $80 \%$ of all local varieties as susceptible to extreme drought, during the diagnosis of the diversity of dryland rice made by Pinto (2017). The seeds maintainers had considered nine varieties, or $26 \%$ of the varieties used in this study, as drought resistant (10, 13, 22, 31, 34, 59, 83, 98 and 103). Of these, only varieties 31 and 34 were actually among the most drought tolerant in this study.

The water balance is one of the main factors affecting plant growth and development. The decrease in external osmotic potential causes an accumulation of solutes in the cells and reduces the capacity of maintaining turgidity pressure (Navarro, Garrido, Martinez \& Carvajal, 2003). Some of the common physiological responses to hydric stress in rice are reduced photosynthetic activity, accumulation of organic acids and changes in carbohydrate metabolism (as the accumulation of soluble carbohydrates in plant cells due to reduced transport of soluble sugar under water stress). Water stress also increases the formation of reactive oxygen species, resulting in lipid peroxidation, protein denaturation and damage to nucleic acids (Hansen, Go \& Jones, 2006). Lanna et al. (2021) identified distinct strategies between rice varieties as responses for water deficit, such as higher ability to save water in leaves, lower leaf water potential, higher ability to reduce vegetative structures, higher efficiency in use of water and improved ability to absorb water from drying soil, either by osmotic adjustment or by additional investment in the root system.

In the face of these physiological responses, severe or prolonged hydric stresses have the potential to cause significant damage to the overall metabolism of rice plants.

The method proposed by $\mathrm{Zu}$ et al. (2017) allows the data to be obtained in the first 45-60 days of cultivation, not requiring the conduction of populations or varieties until the end of the cycle. This procedure for evaluating the potential of genotypes to hydric stress is an advantage for research and experimentation, especially in the initial stages of a genetic improvement program, in which many genotypes are evaluated. 
In order to better use and apply the drought tolerance planning data established in this work for local dryland rice varieties in the far west of Santa Catarina, new studies are needed on the actual soil conditions in the municipalities where the seeds originate, especially the water saturations prevalent in the main cultivation sites during dry periods.

With these data, together with the phenological information obtained by Pinto (2017), reliable recommendations can be established for planting seasons and soil and climate zoning, pointing out to farmers the best growing seasons and the risks associated with each variety group and each season, with the goal of avoiding the total loss of varieties due to drought and consequent genetic erosion.

\section{Conclusion}

The local varieties tested have differential drought tolerance responses.

The established ranking contributes as an additional decision factor to farmers who want to start growing dry rice in the region and do not have seeds stored in the family nucleus.

The fifteen varieties positioned in the upper group of DTD averages for severe stress treatment and the six varieties positioned in the upper group of DTD averages for moderate stress treatment can be used as parents in participatory or formal genetic improvement programs for water stress resistance in a climate change scenario, especially the varieties 61,71 and 82 that were positioned among the most resistant in the two applied stress levels.

\section{References}

Adhikari, M., Adhikari, N. R., Sharma, S., Gairhe, J., Bhandari, R. R. \& Paudel, S. (2019). Evaluation of Drought Tolerant Rice Cultivars Using Drought Tolerant Indices under Water Stress and Irrigated Condition. American Journal of Climate Change, 8, 228-236.

Blum, A. (2016). Osmotic adjustment is a prime drought stress adaptive engine in support of plant production. Plant Cell Environment, 40, 4-10.

Counce, P. A., Keisling, T. C. \& Mitchell, A. J. A. (2000). Uniform, objective, and adaptative system for expressing rice development. Crop Science, 40 (2), 436-443.

Dingkuhn, M., De, D. S., Dorffling, K., Javellana, C. \& Datta, S. (1989). Varietal differences in leaf water potential, leaf net CO2 assimilation, conductivity, and water use efficiency in upland rice. Australian Journal of Agriculture Research, 40, 1183-1192.

Eid, M. \& Sabry, S. (2019). Assessment of Variability for Drought Tolerance Indices in Some Wheat (Triticum aestivum L.) Genotypes. Egyptian Journal of Agronomy, 41 (2), 79-91.

Ferreira, D. F. (2019). Sisvar: a computer analysis system to fixed effects split plot type designs. Revista brasileira de Biometria, 37(4), 529-535.

Freitas, M. J. C. C. \& Oliveira, F. H. (orgs.). (2020). Estiagem no Oeste Catarinense: diagnóstico e resiliência (Relatório Técnico-científico). Florianópolis: EDUNI, 2018. http://www.defesacivil.sc.gov.br/images/ESTIAGEM_NO_OESTE miolo_180417.pdf.

Garg, H. S. \& Bhattacharya, C. (2017). Drought tolerance indices for screening some of rice genotypes. IJABR, 7 (4) 671-674.

Gondim, R. S., Figueiredo, M. C. B., Maia, A. H. N., Bezerra, M. A., \& Carvalho, C. A. C. (2017). Mudanças climáticas e agricultura. EMBRAPA.

Hansen J. M., Go, Y. M. \& Jones, D. P. (2006). Nuclear and mitochondrial compartmentation of oxidative stress and redox signaling. Annual Review Pharmacology Toxicology, 46, 215-34.

Intergovernmental Panel on Climate Change. (2013). Climate Change 2013: the physical science basis. Cambridge University Press. http://climatechange2013.org.

Irri. (2019). Climate Change - Ready Rice, https://www.irri.org/climate-change-ready-rice.

Jaldhani, V., Sengutuvel, P., Srikanth, B., Rao, P. R., Subrahmanyam, D. \& Rao, D. S. (2021). Present status and future prospects of drought tolerance in rice. Cereal Grains. IntechOPen

Ji, K., Wang, Y. \& Sun, W. (2012). Drought-responsive mechanisms in rice genotypes with contrasting drought tolerance during reproductive stage. Journal of Plant Physiology, 169 (4), 336-344.

Kumar, S., Dwivedi, S., Singh, S. S., Jha, S., Sathee, L., Rajamanickam, E. \& Bhatt, B. P. (2014). Identification of drought tolerant Rice genotypes by analyzing drought tolerance indices and morpho-physiological traits. SABRAO Journal Breeding Genetics, 46, 217-230. 
Research, Society and Development, v. 10, n. 8, e55310817705, 2021

(CC BY 4.0) | ISSN 2525-3409 | DOI: http://dx.doi.org/10.33448/rsd-v10i8.17705

Lana, M. A., Eulenstein, F. \& Schlindwein, S. L. (2017). Yield stability and lower susceptibility to abiotic stresses of improved open-pollinated and hybrid maize cultivars. Agronomy Sustainable Development. 37, 30-42.

Lanna, A. C., Coelho, G. R. C., Moreira, A. S., Terra, T. G. R., Brondani, C., Saraiva, G. R., Lemos, F. S., Guimarães, P. H. R., Morais Jr., O. P. M. \& Vianello, R. P. (2021). Upland rice: phenotypic diversity for drought tolerance. Scientia Agricola, 78 (5), 1-14.

Marchesan, J. \& Comassetto, V. (2019). Água e desenvolvimento regional: o caso da mesorregião oeste de Santa Catarina. Revista Brasileira de Assuntos Regionais e Urbanos, 5 (1), 19-38.

Navarro, J. M., Garrido, C., Martínez, V., \& Carvajal, M. (2003). Water relations and xylem transport of nutrients in pepper plants grown under two different salts stress regimes. Plant Growth Regulations, 41, 237-245.

Ouk, M., Basnayake, J., Tsubo, M., Fukai, S., Fischer, K. S., Cooper, M. \& Nesbitt, H. (2006). Use of drought response index for identification of drought tolerant genotypes in rainfed lowland rice. Field Crops Research, 99 (1), 48-58.

Pinto, T. T. (2017). A cultura do arroz de sequeiro no Extremo Oeste de Santa Catarina: diversidade, conhecimentos associados e riscos de erosão genética de variedades locais conservadas pela agricultura familiar. 172 p. Tese (Doutorado). Universidade Federal de Santa Catarina, Florianópolis.

Pinto, T. T., Ogliari, J. B., Maghelly, O. R. (2019). Phenotypic characterization of dryland rice (Oryza sativa L.) germplasm conserved in situ (on farm) in a crop-diversity microcenter in southern Brazil. Genetic Resources and Crop Evolution, 66 (2), 417-4227.

Sabagh, A. E., Hossain, A., Barutçular, C., Khaled, A. A., Fahad, S., Anjorin, F. B., Islam, M. S., Ratnasekera, D., Kizilgeçi, F., Yadav, G. S., Yildirim, M., Konuskan, O. \& Saneoka, H. (2018). Sustainable maize (Zea mays L.) production under drought stress by understanding its adverse effect, survival mechanism and drought tolerance indices. Journal of Experimental Biology and Agricultural Sciences, 6 (2), $282-295$.

Sahebi, M., Hanafi, M. M., Raffi, M. Y, Mahmud, T. M. M., Azizi, P., Osman, M., Abiri, R., Taheri, S., Kalhori, N., Shabanimofrad, M., Miah, G. \& Atabaki, N. (2018). Drought Tolerance in Rice (Oryza sativa L.): Genetics, Genomic Tools, and the WRKY Gene Family. Biomed Research International, 1, 60-80.

Shanker, A. K., Maheswari, M., Yadav, S. K., Desai, S., Bhanu, D., Attal, N. B. \& Venkateswarlu, B. (2014). Drought stress responses in crops. Functional Integrated Genomics, 14, 11-22.

Sokal, R. \& Rohlf, F. (2012). Biometry: the principles and practice of statistics in biological research.

Stone, L. F., Libardi. P. L. \& Reichardt, K. (1986). Produtividade do arroz e absorção de nitrogênio afetadas pelo veranico e pela adição de vermiculita ao solo. Pesquisa Agropecuária Brasileira, 21, 117-125.

Xiao, B. Z., Chen, X., Xiang, C. B., Tang, N., Zhang, Q. F. \& Xiong, L. Z. (2009). Evaluation of seven function-known candidate genes for their effects on improving drought resistance of transgenic rice under field conditions. Molecular Plant, 2, 73-83.

Zu, X., Lu, Y., Wang, Q., Chu, P., Miao, W., Wang, H. \& La, H. (2017). A new method for evaluating the drought tolerance of upland rice cultivars. The Crop Journal, 5, 488-498. 